\title{
LEVEL OF FINANCIAL LITERACY \\ OF ACADEMIC YOUTH FROM RURAL AREAS IN THE VISEGRAD GROUP COUNTRIES
}

\author{
Monika Szafrańska \\ University of Agriculture in Cracow, Cracow, Poland \\ e-mail: m.szafranska@ur.krakow.pl \\ ORCID: 0000-0002-4948-7636 \\ (C) 2019 Monika Szafrańska \\ This is an open access article distributed under the Creative Commons Attribution-NonCommercial- \\ NoDerivs license (http://creativecommons.org/licenses/by-nc-nd/3.0/)
}

DOI: 10.15611/fins.2019.3.05

JEL Classification: I21, I22, I25

\begin{abstract}
The aim of the study is to determine the level of financial literacy of academic youth from rural areas in the V4 Group countries, as well as to compare the results obtained with the level of financial literacy of young people from cities. The source of data used for analysis and inference were primary information obtained from own research (PAPI method, 900 people). The research used a set of questions to assess the level of financial literacy of adults proposed by the OECD INFE. In addition to primary sources, secondary sources were also used to achieve the goal. The measures of descriptive statistics and one-way analysis of variance (F) were used. The level of financial literacy was determined at the medium level, which may indicate the low effectiveness of financial education measures implemented at different levels of education. The component of financial literacy where students from rural areas had the lowest scores was basic financial knowledge. Only $43 \%$ of people from rural areas achieved the minimum target score.
\end{abstract}

Keywords: financial awareness, university students, village, V4 Group.

\section{Introduction}

In the literature, the term financial literacy is defined, in the narrow sense, as the knowledge of the basic financial concepts needed to make rational financial decisions concerning saving, investment, incurring financial liabilities and insurance. In the broad sense, financial literacy, in addition to basic financial knowledge, also includes skills, attitudes and appropriate financial behaviour [OECD 2016]. According to numerous studies, a high level of financial literacy of citizens, especially young people, is one of the most important competences in the 21st century [Ajzerle et al. 2013; Luksander et al. 2014; OECD INFE 2016; Kubak et al. 2018]. An increase in the level of financial literacy can solve such problems as low levels of savings, 
high indebtedness of households and the inability to effectively use available financial products [Santos, Abreu 2013; Chmeliková 2015; Solarz 2015; Musiał 2018].

One of the factors differentiating the level of financial literacy of citizens is their place of residence (rural/urban areas). Numerous studies indicate that the inhabitants of non-urbanized areas are characterised by a much lower level of financial literacy compared to the inhabitants of cities [Lusardi, Mitchell 2014; Kata et al. 2015; Gaisina, Kaidarova 2017]. In addition, the statistics reveal huge disparities in these areas, especially when taking into account poor countries [Xu, Zia 2013; Bendre, Singh 2017; Karakurum-Ozdemir et al. 2018]. The differences are also noticeable in more developed regions such as Europe. The developing countries of Central and Eastern Europe represent definitely a less favourable level of financial literacy in comparison to the most developed countries of Western Europe [Smyczek 2016; Frączek et al. 2017]. This is due, among others, to the poorer access of rural residents to educational, financial and ICT infrastructure [Bański 2018].

According to scientists, in recent years the development gaps between urban and rural areas of the V4 Group countries have continued to decrease, as shown by the most important indicators characterizing the level of social and economic development, as well as the similarity of educational aspirations and consumption patterns for the rural areas and the rest of the country [Straka, Tuzová 2016; Székely 2018; Dimeski, Tosheva 1018; Wilkin, Nurzyńska 2018]. The young generation of this environment is more and more willing to take up the challenges of the modern economy, and wants to decide their own fate more than the generation of their parents.

Research on determining the level of financial literacy has been undertaken in the Visegrad Group Countries for many years. Most often they refer to determining the general level of financial literacy of the population in each country (Czech Republic - [Hedvicaková, Svobodová 2018]; Hungary - [Endre et al. 2011; Botos et al. 2012; Németh et al. 2016]; Poland - [Citi Handlowy 2009; Iwanicz-Drozdowska 2011; Kieżel, Burgiel 2017]; Slovakia - [Zvariková, Majerová 2014]). In several studies, an attempt was made to characterize the level of financial literacy of students, but most often these are surveys carried out in accordance with the original questionnaires, which makes it impossible to compare the results between countries (Czech Republic - [Chmeliková 2015; Beranová et al. 2017]; Hungary [Pintye, Kiss 2016; Nemeth, Zsóter 2018]; Poland - [Iwanicz-Drozdowska 2011; Golawska-Witkowska et al. 2016]; Slovakia - [Hornyák-Gregáňová, Pietriková 2018; Kubak et al. 2018]). However, there is a lack of detailed research to determine the level of financial literacy including the knowledge, behaviour and financial attitudes of selected social groups using the same methodology.

The aim of the study is to determine the level of financial literacy of academic youth from rural areas in the Visegrad Group countries, as well as to compare the results obtained with the level of financial literacy of young people from cities. Knowing the level of financial literacy of young people from rural areas will enable 
entities responsible for the financial education of society to prepare the appropriate initiatives and educational projects taking the special educational needs of the beneficiaries in this area into account.

\section{Material and methods}

The primary source of data used for analysis and inference were primary information obtained from own research. The research was carried out in 2018 using the PAPI method on a group of 900 people. People from rural areas accounted for $40 \%$ of the surveyed population. The interview was conducted with students studying in the V4 Group Countries in four academic centres: Brno (Czech Republic, 225 respondents), Gődőllo (Hungary, 222 respondents), Kraków (Poland, 225 respondents) and Nitra (Slovakia, 228 respondents). The selection of the test sample was deliberate. The study was attended by students who expressed their willingness to complete the questionnaire.

Of the people who participated in the study, $67 \%$ were women and $33 \%$ were men. Almost $40 \%$ of students worked during their studies. The group was dominated by second-cycle students (55\%) and non-economic students (62\%).

The research used a set of questions to assess the level of financial literacy of adults proposed by the OECD INFE [2011]. The OECD INFE methodology for conducting surveys on financial literacy was chosen because OECD INFE conducted surveys according to an identical questionnaire in several dozen countries around the world, which allows for the comparability of the obtained results.

The questionnaire form consisted of four parts and contained 24 single-choice questions of a closed nature. The first part was the respondent's particulars (5 questions). Subsequent parts concerned the individual components of financial literacy: basic financial knowledge ( 7 questions), financial behaviour ( 9 questions) and financial attitudes (3 questions). In addition to the primary sources, secondary sources were also used to achieve the goal.

According to the OECD INFE assumptions, in order to compare the results across countries, the average number of points for the financial literacy index and its individual modules was calculated in the analysis. In addition, for the modules: basic financial knowledge, behaviour and attitudes, the minimum target score was calculated. The minimum target result is the share of people in the studied population who obtained $70 \%$ correct answers in the given module (basic financial knowledge -more than 5 correct responses, financial behaviour -6 and more correct responses, financial attitudes - more than 3 correct responses) [OECD 2016].

Structure indicators, the minimum, the maximum, the mean (M) and the standard deviation (SD) were used in the descriptive analysis of the results. In order to compare the mean, estimates made by k-independent groups of respondents, a one-way analysis of variance (the F test) was used. This method is used when: 
1. The analyzed variable is measurable.

2. Considered $k$-independent populations have normal distributions.

3. These distributions have the same variance (assumption of homogeneity of variance).

The basis for analysis of variance is the possibility of breaking the sum of squares of the total variance for all observation results into two components:

- sum of squares describing the variability inside the samples,

- sum of squares describing the variability between groups (populations).

To estimate the value of the $F$ test, the following formula was used [Stanisz 2006]:

$$
\mathrm{F}=\mathrm{MS} \text { between groups : MS inside groups, }
$$

MS - Mean Squares.

The values of the $\mathrm{F}$ test above unity indicate the need to reject the $\mathrm{H}_{0}$ hypothesis. The $\mathrm{H}_{0}$ hypothesis assumes that the averages in separate groups of respondents are the same

$$
\mathrm{H}_{0}: \mu_{1}=\mu_{2}=\ldots=\mu_{k}
$$

$\mu$ - the average value characterizing the population, against the $\mathrm{H} 1$ alternative hypothesis assuming that at least two averages differ from each other

$$
\mathrm{H}_{1}: \mu 1 \neq \mu 2 \text { or } \mu 1 \neq \mu 3 \text { or } \mu 2 \neq \mu 3 \text {. }
$$

If the analysis of variance (the $\mathrm{F}$ test) does not show significance between the analyzed averages, no further tests are carried out. However, when the $\mathrm{H}_{0}$ hypothesis is rejected in the analysis of variance, it is necessary to carry out a more detailed study of the differences between the means of individual groups (post-hoc tests) [Stanisz 2006]. In order to establish statistically significant differences between the average mean, a RIR Tukey post-hoc test was performed. The adopted level of significance for all analyses was 0.05 .

The research results are presented in a descriptive, table and graphic form.

\section{Financial knowledge, behaviour and attitudes of academic youth}

In order to calculate the general indicator characterising the level of students' financial literacy, the OECD INFE methodology was applied. The final version of the questionnaire (the core questionnaire ) was approved at the $8^{\text {th }}$ Meeting of the International Network on Financial Education on 26 October 2011 in Cape Town, South Africa [OECD INFE 2011]. The questionnaire is specifically designed to be applicable across people of different education and income levels as well as 
in markets with different levels of financial inclusion. Secondly, it is designed to collect comparable information on the financial attitudes, behaviour and knowledge of the adult population that can be used to create scores to indicate their overall financial literacy level [OECD INFE 2016].

The level of financial literacy indicator is the sum of the results obtained in the three modules forming the respondent's financial literacy: basic financial knowledge, behaviour and attitudes.

The core questionnaire includes seven questions designed to test basic financial knowledge. The respondent receives 1 point for each correct answer. Respondents can get a minimum of 0 points and a maximum of 7 points (Table 1). In the next part (financial behaviour) the maximum number of points is 9 (nine questions, 1 point for each correct answer). The questionnaire includes three questions to assess the respondent's attitudes towards money (the third module of financial literacy). Respondents use a scale to indicate whether he/she agree or disagree with particular statements (the five-point Likert scale is used). In this part, the points marked by the respondent are addeed up and the obtained value is divided by 3 . The minimum number of points from this module is 1 and the maximum 5 .

Table 1. Minimum and maximum number of points in financial literacy modules

\begin{tabular}{|l|c|c|}
\hline \multicolumn{1}{|c|}{ Specification } & Minimum number of points & Maximum number of points \\
\hline Financial knowledge & 0 & 7 \\
\hline Financial behaviour & 0 & 9 \\
\hline Financial attitudes & 1 & 5 \\
\hline Financial literacy (total) & 1 & 21 \\
\hline
\end{tabular}

Source: [OECD INFE 2016].

After adding up the result from each module creating financial literacy (financial knowledge, behaviour and attitudes), we obtain the overall result. The minimum value of the financial literacy indicator is 1 point, the maximum is 21 points.

According to the survey, students from rural areas in all countries of the V4 group have a lower level of financial literacy compared to respondents from cities (Figure 1). However, the difference in the results is not significant, in the case of the average for the examined group it is 0.8 points. The highest differentiation was observed for young people from the Czech Republic (a difference of 1.2 points), while the lowest in the case of respondents from Poland ( 0.5 points). The average result obtained for the study group was lower than the average result obtained for the adult population of inhabitants of V4 countries [OECD 2016]. The results obtained are consistent with those of other researchers, which show that people under 25 years of age have a low level of financial literacy [Stănculescu 2010]. 


\section{0}

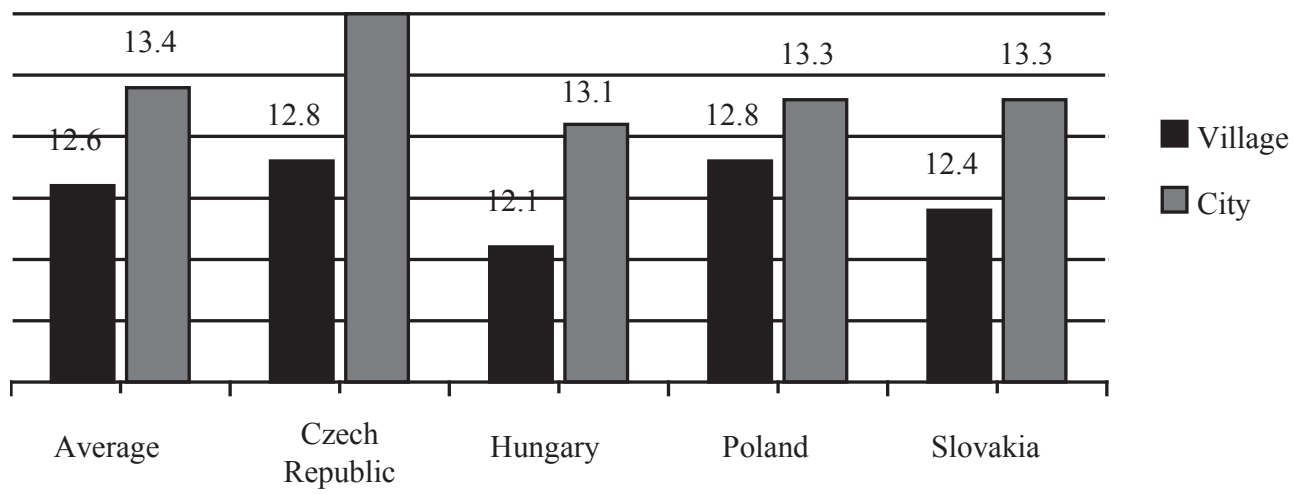

Fig. 1. The level of financial literacy of students in the V4 Group Countries according to their area of residence [points]

Source: own study.

Table 2. Financial literacy (average scores, points)

\begin{tabular}{|l|c|c|c|c|}
\hline \multicolumn{1}{|c|}{ Specification } & $\begin{array}{c}\text { Village } \\
\text { M (SD) }\end{array}$ & $\begin{array}{c}\text { City } \\
\text { M (SD) }\end{array}$ & $F$ & $p$ \\
\hline Average for total group & $12.6(3.35)$ & $13.4(3.02)$ & $F=4.51$ & $p=0.0300^{*}$ \\
\hline Czech Republic & $12.8(3.2)$ & $14.0(1.8)$ & $F=9.94$ & $p=0.0018^{*}$ \\
\hline Hungary & $12.1(2.9)$ & $13.1(3.3)$ & $F=3.71$ & $p=0.0554$ \\
\hline Poland & $12.8(3.5)$ & $13.3(2.7)$ & $F=0.65$ & $p=0.4200$ \\
\hline Slovakia & $12.4(3.8)$ & $13.3(3.3)$ & $F=5.97$ & $p=0.0150^{*}$ \\
\hline
\end{tabular}

* Differences between means statistically significant at $p \leq 0.05$.

Source: own study.

According to the one-way analysis of variance (Table 2), the average values obtained regarding young people from the Czech Republic $(F=9.94)$ and Slovakia $(F=5.97)$ differ significantly depending on the place of residence of the respondents.

Table 3. Financial knowledge (average scores, points)

\begin{tabular}{|l|l|l|l|c|}
\hline \multicolumn{1}{|c|}{ Specification } & $\begin{array}{c}\text { Village } \\
\text { M (SD) }\end{array}$ & $\begin{array}{c}\text { City } \\
\text { M (SD) }\end{array}$ & $F$ & $p$ \\
\hline Average for total group & $4.3(1.6)$ & $4.9(1.5)$ & $F=9.38$ & $p=0.0020^{*}$ \\
\hline Czech Republic & $4.5(1.6)$ & $5.1(1.6)$ & $F=6.46$ & $p=0.0010^{*}$ \\
\hline Hungary & $4.1(1.3)$ & $4.6(1.4)$ & $F=6.35$ & $p=0.0120^{*}$ \\
\hline Poland & $4.4(1.7)$ & $5.1(1.5)$ & $F=23.39$ & $p=0.0002^{*}$ \\
\hline Slovakia & $3.9(1.5)$ & $4.9(1.5)$ & $F=5.97$ & $p=0.0150^{*}$ \\
\hline
\end{tabular}

* Differences between means statistically significant at $p \leq 0.05$.

Source: own study. 
One of the components of financial literacy is basic financial knowledge. This knowledge enables consumers to compare financial services in the market and make rational decisions about personal finance. On average, students from rural areas received 4.3 points from this part of the study group (Table 3). Every tenth respondent answered only one question correctly, while $5 \%$ of students achieved a maximum score of 7 points. According to a one-way analysis of variance, statistical differences in the level of students' financial literacy were observed for all countries due to the place of residence of young people. Students from rural areas were characterised by a lower level of basic financial knowledge compared to their peers from cities.

For each component of financial literacy, the OECD INFE has defined a minimum target score, which is presented in percentage terms. This is the minimum result that every citizen should have in order to make informed decisions in the financial markets. For this financial literacy component the target score was set at a minimum of 5 correct answers, representing $70 \%$ of all the questions in this section [OECD INFE 2016]. The values obtained for the target result are shown in Figure 2.

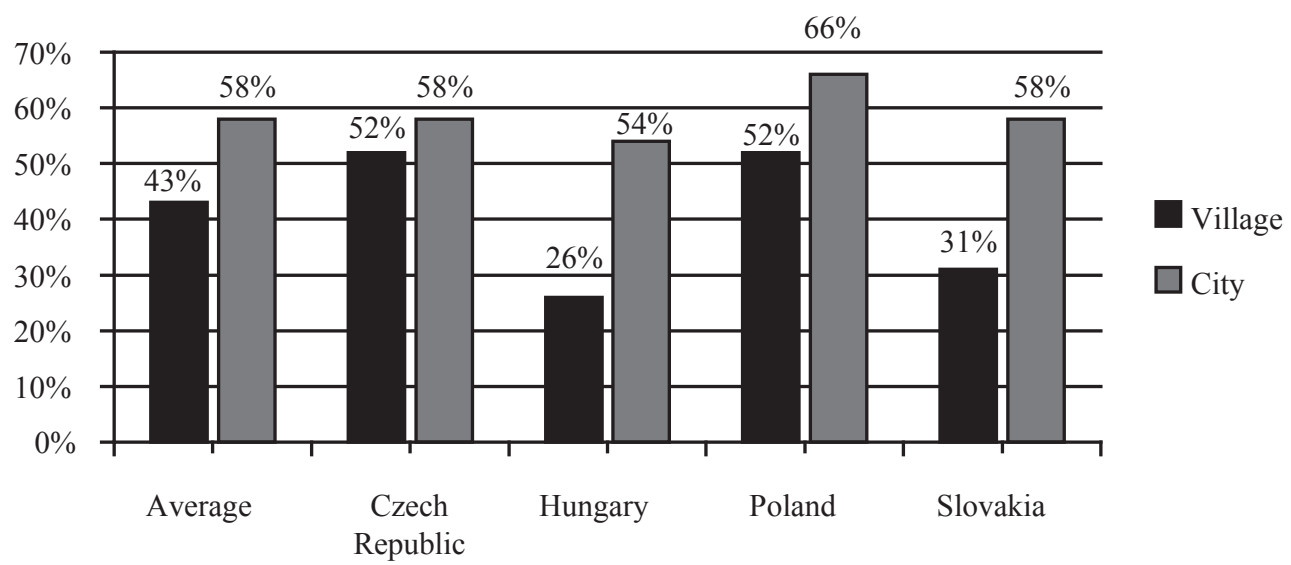

Fig. 2. Financial knowledge of students in the V4 Group Countries according to their area of residence (minimum target score, more than 5 responses) [\%]

Source: own study.

The analysis of the minimum target score confirms the previously-selected dependence that students from rural areas have a lower level of financial knowledge in comparison with their peers from cities. According to the conducted research, only $43 \%$ of students from rural areas participating in the study achieved the assumed minimum result (Figure 2). The presented values for young people living in non-urbanized areas are 15 percentage points lower than the average result calculated for respondents from cities. At the same time, the results obtained for the group of students coincide with the results obtained by other researchers [Chmeliková 
2015; Frączek et al. 2017]. The lowest proportion of students from rural areas who gave at least $70 \%$ of the correct answers, was noted for respondents from Hungary, the best results were achieved by students from the Czech Republic and Poland. The highest difference in the results between students from non-urbanised areas and cities occurred in the case of Hungary (28 percentage points), the lowest differences in results were observed for Czech students (6 percentage points).

The questions that caused the most problems for the students were the knowledge of the calculation of compound interest and the variable value of money over time. This information should be taken into account when designing financial literacy education for young people. According to Lusardi and Mitchell [2014], knowledge of basic financial concepts such as the current value of money or simple or compound interest has a positive impact on retirement planning and saving for retirement, and thus financial well-being. Similar results were also reported by Alessie et al. [2011].

The second component of financial literacy is financial behaviour. Students' financial behaviour was assessed by means of 9 questions. The average score for this group is 6 correct answers. Two respondents did not answer any questions correctly, while $7.5 \%$ of the students from rural areas received the maximum score. On the basis of the results obtained, it can be concluded that there were no differences in the average score obtained in this part of the test between a group of students from rural areas and cities. The $p$-factor in each case was greater than 0.05 , which allows us to assume a zero hypothesis that the average results in the analysed groups of students are not differentiated (Table 4).

Table 4. Financial behaviour (average scores, points)

\begin{tabular}{|l|c|c|c|c|}
\hline \multicolumn{1}{|c|}{ Specification } & $\begin{array}{c}\text { Village } \\
\text { M (SD) }\end{array}$ & $\begin{array}{c}\text { City } \\
\text { M (SD) }\end{array}$ & $F$ & $p$ \\
\hline Average for total group & $5.7(2.1)$ & $5.8(1.6)$ & $F=0.08$ & $p=0.7700$ \\
\hline Czech Republic & $5.8(1.8)$ & $6.2(1.4)$ & $F=2.90$ & $p=0.0900$ \\
\hline Hungary & $5.7(2.0)$ & $5.7(1.9)$ & $F=0.07$ & $p=0.7900$ \\
\hline Poland & $5.7(2.0)$ & $5.6(1.2)$ & $F=2.08$ & $p=0.1500$ \\
\hline Slovakia & $5.5(2.4)$ & $5.8(2.0)$ & $F=0.95$ & $p=0.3300$ \\
\hline
\end{tabular}

* Differences between means statistically significant $p \leq 0.05$.

Source: own study.

The minimum target score in this part was at least 6 correct responses [OECD INFE 2016]. Figure 3 presents the percentage share of the respondents from the individual countries that achieved the assumed target result.

According to the conducted analysis, slightly more than half of the respondents achieved the assumed minimum result (Figure 3, 53\%). Taking into account the country in which a young person studies, it can be concluded that in most countries the result obtained by students from rural areas was lower than the result obtained by respondents from urban areas (the Czech Republic, Poland, Slovakia). In the case 


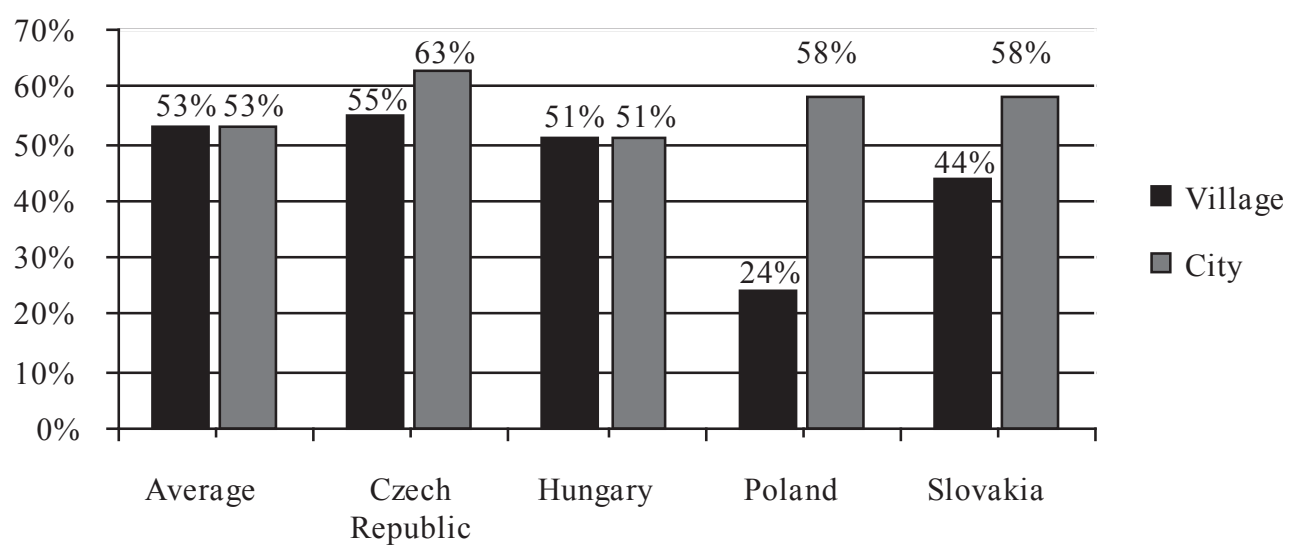

Fig. 3. Financial behaviours of students in the V4 Group Countries according to their area of residence (minimum target score, 6 and more correct responses) [\%]

Source: own study.

of Hungary there was no variation in the results obtained by the place of residence (village/city). In the group of students from rural areas, the most correct answers were given by Czech students (55\%), the least by Polish students (24\%). For the Polish respondents there was also a significant difference in the results obtained between students from non-urbanised areas and city dwellers (34\%).

Table 5. Financial attitudes (average scores, points)

\begin{tabular}{|l|c|c|c|c|}
\hline \multicolumn{1}{|c|}{ Specification } & $\begin{array}{c}\text { Village } \\
\text { M (SD) }\end{array}$ & $\begin{array}{c}\text { City } \\
\text { M (SD) }\end{array}$ & $F$ & $p$ \\
\hline Average for total group & $2.6(1.3)$ & $2.7(1.2)$ & $F=0.78$ & $p=0.0700$ \\
\hline Czech Republic & $2.5(1.1)$ & $2.7(1.2)$ & $F=1.67$ & $p=0.2000$ \\
\hline Hungary & $2.3(1.1)$ & $2.8(1.3)$ & $F=4.36$ & $p=0.0370^{*}$ \\
\hline Poland & $2.7(1.4)$ & $2.6(1.1)$ & $F=0.15$ & $p=0.7000$ \\
\hline Slovakia & $3.0(1.5)$ & $2.6(1.2)$ & $F=5.89$ & $p=0.0016^{*}$ \\
\hline
\end{tabular}

* Differences between means statistically significant at $p \leq 0.05$.

Source: own study.

Another component of financial literacy is financial attitudes. The questionnaire included three questions to assess the respondents' attitudes towards money and financial planning. The statements used in the questionnaire were as follows: "Money is there to be spent", "I tend to live for today and let tomorrow take care of itself", "I find it more satisfying to spend money than to save it for the long term". For the assessment of attitudes, a five-step Likert scale was used, where 1 meant that the student fully agreed with the statement, 5 - completely disagreed. The content of the questions concerned short-term postures, so if the respondent did not agree 
with the statement (answers 4 and 5) it meant that he or she had such an attitude in a longer time horizon. The points marked by the respondents were added up and the value obtained was divided by 3 . The average score obtained by a group of students from rural areas is 2.6 points out of a possible 5 for this part. Most students received 2 points, and $15 \%$ of people in rural areas achieved the maximum of 5 points. According to the statistical analysis, in two countries, Slovakia and Hungary, differences in financial attitudes between rural and urban youth were observed. Slovak students from rural areas received a higher score compared to their peers from cities. The opposite trend was characteristic of Hungarians (Table 5).

According to the OECD INFE methodology [2016], the expected result characterizing the financial attitudes of respondents is a value above 3 points. Figure 4 presents the percentage share of respondents who achieved the assumed result.

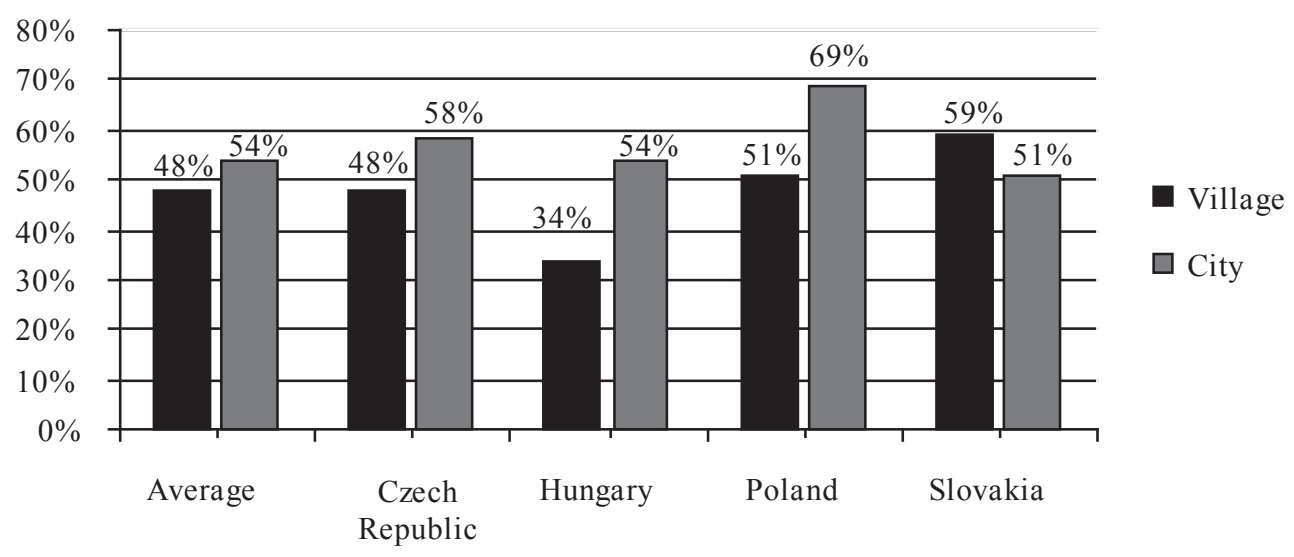

Fig. 4. Financial attitudes of students in V4 Group Countries according to their area of residence (minimum target score, more than 3 correct responses) [\%]

Source: own study.

According to the conducted survey, in most countries of the V4 Group the results obtained by students from rural areas were lower than those of urban residents (Figure 4). The largest disproportions were observed in Poland (18 percentage points difference). The opposite relationship was observed in Slovakia, where students from rural areas achieved higher results. The results obtained coincide with the results presented in the literature [OECD INFE 2016].

\section{Conclusion}

The conducted survey made it possible to determine the level of financial literacy of academic youth from rural areas in the Visegrad Group countries. Despite the decreasing development distances between the modern rural and urban areas, an increase in the level of education of rural youth, as well as changes in their 
attitudes and life aspirations, students from non-urbanized areas in the V4 countries are still characterised by a lower level of financial literacy in comparison to their peers from cities.

The level of financial literacy was determined at the medium level (financial literacy indicator $=12.6$ points), which may indicate the low effectiveness of financial education measures implemented at different levels of education. In order to increase the effectiveness of the implemented activities, the planned educational initiatives should pay attention to the selection of appropriate teaching tools and methods. Both traditional methods and methods specific to new technologies should be used in the process of financial education. This applies to both pre-university and academic education.

The component of financial literacy where students from rural areas had the lowest scores was basic financial knowledge. Only $43 \%$ of people in rural areas achieved the assumed result. For this component, statistically significant differences in the level of financial knowledge between young people from non-urbanised areas and students from cities were also found. The greatest lack of knowledge was observed regarding basic financial terms such as compound interest or the purchasing power of money. Therefore in educational programmes and projects in the field of personal finance dedicated to rural youth, special attention should be paid to this module of financial literacy. It should be remembered that appropriate financial education of young consumers will prepare them for active and conscious participation in the financial markets in the future.

In order to design appropriate educational activities for young people from rural areas, both through governmental and non-governmental organizations, as well as to monitor the dynamics of changes in the level of financial literacy of academic youth, there is a need to continue research in this area in future.

\section{References}

Alessie R., Van Rooij M., Lusardi A., 2011, Financial literacy and retirement preparation in the Netherlands, Journal of Pension Economics and Finance, 10(5), pp. 527-545.

Ajzerle S., Brimble M., Freudenberg B., 2013, Is financial capability related to the effective use of debt in Australia?, Australian Accounting Business \& Finance Journal, 7/3, pp. 107-128.

Bański J., 2018, Phases to the transformation of agriculture in Central Europe - selected processes and their results, Agric. Econ. - Czech, 64, pp. 546-553.

Bendre A., Singh V., 2017, Financial literacy paving the way for financial inclusion in India, International Journal of Engineering Technology Science and Research, 4/12, pp. 359-370.

Beranová M., Navrátilová M., Šišková J., Stárová M., 2017, Financial literacy of university students in relation to financial security in old age, ERIE, 1, pp. 25-32.

Botos K., Botos J., Béres D., Csernák J., Németh E., 2012, Financial literacy and risk-taking of households in the hungarian central great plain, Public Finance Quarterly, 3, pp. 267-285. 
Chmeliková B., 2015, Financial literacy of students of finance: An empirical study from the Czech Republic, International Journal of Economics and Management Engineering, 9/12, pp. 4233-4236.

Citi Handlowy, 2009, The State of Financial Knowledge of Poles. Report of the Kronenberg Foundation at Citi Handlowy, Dom Badawczy Maison, Warszawa.

Dimeski B., Tosheva E., 2018, Examining rural regions in Hungary after EU accession: Public management of some key performance (2004-2014), Balkan Social Science Review, 12, pp. 7-25.

Endre D., Nagy A., Székely L., 2011, Financial literacy in the Hungarian civil sector, Civil Szemke 8 (1-2), pp. 1-69.

Frączek B., Bobenič Hintošová A., Bačová M., Siviček T., 2017, Simultaneous use of the financial literacy level and the financial inclusion degree as a result of financial education efficiency in Visegrad Group countries, Journal of Economics and Management, 27(1), pp. 5-25.

Gaisina S., Kaidarova L., 2017, Financial literacy of rural population as a determinant of saving behavior in Kazakhstan, Rural Sustainability Research, 38 (333), pp. 32-42.

Golawska-Witkowska G., Mazurek-Krasodomaska E., Rzeczycka A., 2016, Financial literacy of Technical Universities' Students Using the Example of Gdańsk University of Technology and its Determinants, [in:] Wieteska S., Burzyńska D. (eds.), Granice finansowe XXI wieku - finanse publiczne, rynek finansowy, finanse przedsiębiorstw, Wydawnictwo Uniwersytetu Łódzkiego, Łódź, pp. 35-48.

Hedvicaková M., Svobodová L., 2018, Web portals used in financial education as a support of financial literacy, Advanced Science Letters, 24/4, pp. 2948-2952(5).

Hornyák-Gregáňová R., Pietriková M., 2018, Financial literacy of students of the Slovak University of Agriculture in Nitra, Mathematics in Education, Research and Applications, 3/2, pp. 79-84.

Iwanicz-Drozdowska M. (ed.), 2011, Edukacja i świadomość finansowa, Oficyna Wydawnicza Szkoła Główna Handlowa w Warszawie, Warszawa.

Karakurum-Ozdemir K., Kokkizil M., Uysal G., 2018, Financial Literacy in Developing Countries. Social Indicators Research, https://doi.org/10.1007/s11205-018-1952-x (25.02.2019).

Kata R., Walenia A., Pyrkosz D., 2015, Financial exclusion of the rural population in Poland, Journal of Agribusiness \& Rural Development, 4(38), pp. 1-10.

Kieżel E., Burgiel A., 2017, Economic Knowledge of Consumers and the Rationality of their Behaviours, Wydawnictwo C.H. Beck, Warszawa.

Kubak M., Tkacova A., Androniceanu A., Tvaronavičiené M., Huculova E., 2018, Financial literacy of students in chosen universities - research platform for regulatory processes of the educational system in Slovakia, Finance, 1, pp. 175-190.

Luksander A., Béres D., Huzdik K., Németh E., 2014, Analysis of the factors that influence the financial literacy of young people studying in higher education, Public Finance Quarterly, 59(2), pp. 220-241.

Lusardi A., Mitchell O., 2014, The economic importance of financial literacy, theory and evidence, JEconLit, 52(1), pp. 5-44.

Musiał M., 2018, Personal finance management effectiveness in Poland, Wydawnictwo Naukowe Uniwersytetu Szczecińskiego, Szczecin.

Musiał M., Świecka B., 2016, Analysis of knowledge and financial skills of the young generation, Acta Universitatis Lodziensis Folia Oeconomica, 6 (326), pp. 203-2016.

Németh E., Jacovác K., Meszáros A., Kollár P., Váralotai V., 2016, Insight and blight-initiatives on enhancing financial literacy in Hungary, Public Finance Quarterly, 3, pp. 401-422.

Németh E., Zsóter B., 2018, Characterisation of young people according to their financial attitudes and behaviours - a survey on the financial behaviour and attitudes of students in higher education, Applied Finance and Accounting, 4/1, pp. 31-40.

OECD INFE, 2011, Measuring Financial Literacy Questionnaire and Guidance Notes for Conducting an Internationally Comparable Survey of Financial Literacy, www.oecd.org/finance/financial-education (15.02.2019). 
OECD INFE, 2016, International Survey of Adult Financial Literacy Competencies, www.oecd.org/ finance/financial-education (15.12.2018).

Pintye A., Kiss M., 2016, Financial literacy of students in business and economics higher education, The Annals of the University of Oradea - Economic Sciences, 25/1, pp. 781-789.

Santos E., Abreu M., 2013, Financial literacy, financial behaviour and individuals'over-indebtedness, ISEG-DE Working Papers, 11/2013/DE/UECE, pp. 1-31.

Smyczek S., 2016, Financial literacy of consumers in the Central and Eastern Europe countries, Zeszyty Naukowe Uniwersytetu Ekonomicznego, 303, pp. 24-35.

Solarz M., 2015, Increasing financial resilience of households as the condition for long-lasting financial inclusion, Annals Universitatis Mariae Curie-Skłodowska, Sectio H - Oeconomia, vol. XLIX,4, pp. 517-525.

Stanisz A., 2011, Przystepny kurs statystyki, StatSoft Polska Sp z o.o., Kraków.

Stănculescu M.S., 2010, Analysis of the Financial Literacy Survey in Romania and Recommendations, World Bank, Washington, DC, https://openknowledge.worldbank.org/handle/10986/12874 License: CC BY 3.0 IGO (25.02.2019).

Straka J., Tuzová M., 2016, Factors affecting development of rural areas in the Czech Republic: A literature review, Procedia - Social and Behavioral Sciences, 220, pp. 496-505.

Székely V., 2018, Rural development and local action groups in Slovakia: International and international comparison, Acta Geobalcanica, 4, pp. 33-39.

Xu L., Zia B., 2013, Financial Literacy in the Developing World. World Bank-Development Research Group, https://papers.ssrn.com (25.02.2019).

Wilkin J., Nurzyńska I., 2018, Rural Poland 2018. The Report on the State of Rural Areas, Scholar, Warszawa.

Zvariková K., Majerová J., 2014, Financial literacy in the Slovak Republic, Procedia-Social and Behavioral Sciences, 10, pp. 1106-1115.

\section{POZIOM ŚWIADOMOŚCI FINANSOWEJ MLODZIEŻY AKADEMICKIEJ Z OBSZARÓW WIEJSKICH W KRAJACH GRUPY WYSZEHRADZKIEJ}

Streszczenie: Cele pracy to określenie poziomu świadomości finansowej młodzieży akademickiej pochodzącej z obszarów wiejskich w krajach Grupy V4 i porównanie uzyskanych wyników z poziomem świadomości finansowej młodych osób pochodzących z miast. Głównym źródłem danych były informacje pierwotne pozyskane z badań własnych (matoda PAPI, 900 respondentów). W badaniach użyto zestawu pytań umożliwiającego ocenę poziomu świadomości finansowej osób dorosłych, zaproponowanego przez OECD INFE. Poza źródłami pierwotnymi wykorzystano również źródła wtórne. Do osiągnięcia celu pracy zastosowano miary statystki opisowej oraz jednoczynnikową analizę wariancji (F). Poziom świadomości finansowej określono jako średni, co może wskazywać na niską efektywność działań z zakresu edukacji finansowej realizowanych na różnych poziomach edukacji. Komponentem świadomości finansowej, w którego przypadku studenci z obszarów wiejskich uzyskali najniższe wyniki, była podstawowa wiedza finansowa. Tylko 43\% osób osiągnęło założony rezultat.

Słowa kluczowe: świadomość finansowa, studenci, obszary wiejskie, kraje Grupy V4. 